\title{
Optimalisasi Potensi Ekonomi Masyarakat Melalui Budidaya Jamur Tiram
}

\author{
Waris \& Nurul Khasanah \\ Institut Agama Islam Negeri Ponorogo \\ Email: waris9503@gmail.com,nkhasanah84@gmail.com
}

\begin{abstract}
This service research aims to open up the entrepreneurial spirit of Mitir community. The development of entrepreneurial spirit will automatically reduce the unemployment class and the working class in Mitir. With the emergence of oyster mushroom entrepreneurs, it is expected to increase the income of the community. The increasing income of the community is related to the increasing level of education of the younger generation in the country. If the level of education has begun to increase, the poverty rate in the following year will be gradually reduced. Through this paper, it is concluded that the presence of outside agents is very necessary for Mitir community. The agent serves to provide knowledge about the cultivation of oyster. With the presence of the agents, will be able to cut people mindset who tend to take it for granted, so that the community have open opportunities to achieve their own desired goals.
\end{abstract}

\begin{abstract}
Abstrak: Penelitian pengabdian ini bertujuan untuk membuka jiwa wirausaha masyarakat dusun Mitir. Berkembangnya jiwa wirausaha akan secara otomatis memangkas kelas pengangguran, kelas buruh di dusun Mitir. Nantinya dengan banyak munculnya wirausahawan jamur tiram maka pendapatan masyarakat meningkat. Peningkatan pendapatan masyarakat berelasi dengan meningkatnya tingkat pendidikan generasi muda di dusun Mitir. Jika tingkat pendidikan sudah mulai mengalami peningkatan maka secara perlahan angka kemiskinan ditahun berikutnya sedikit dapat dikurangi. Melalui tulisan ini disimpulkan adanya agen dari luar sangat diperlukan bagi masyarakat dsn. Mitir. Agen berfungsi untuk memberikan pengetahuan tentang budidaya jamur tiram. Dengan adanya agen akan dapat memotong mata rantai pola pikir masyarakat yang cenderung take it for granted, sehingga masyarakat terbuka peluangnya untuk mencapai tujuan yang dikehendaki sendiri.
\end{abstract}

Kata Kunci: Komunitas, entrepreneur, jamur tiram. 


\section{PENDAHULUAN}

Badegan merupakan salah satu kecamatan di kabupaten Ponorogo yang memiliki luas wilayah 52,35 $\mathrm{km}^{2}$. Kecamatan ini terletak di ujung barat kabupaten Ponorogo dengan ketinggian 160-390 di atas permukaan laut (dpl) dan curah hujan 3-4 bulan berturut-turut/tahun. Menurut Junghun daerah dengan ketinggian 0-600 dpl dikategorikan beriklim panas, akan tetapi SchmidtFerguson mengatakan bahwa daerah dengan curah hujan 3-4 bulan sepanjang tahun dapat dikatakan beriklim basah sedang. Artinya bahwa kecamatan Badegan memiliki iklim yang cenderung lebih sejuk dibandingkan dengan kecamatan lain di daerah kabupaten Ponorogo. Kurang lebih 66,55\% masyarakatnya bermata pencaharian di sektor pertanian khususnya padi. Padi menjadi dewa bagi masyarakat, karena dari sector itulah mereka dapat menyambung nyawa disetiap harinya.

Dominasi pertanian padi sebagai mata pencaharian utama masyarakat Badegan menjadi sebuah ironi. Di saat Indonesia terkepung oleh globalisasi dengan tawaran ragam mata pencaharian, mereka masih mendewakan pertanian sebagai penyuplai asap dapurnya. Lebih jauh pemilihan pertanian padi sebagai mata pencarian utama ternyata mengisyaratkan adanya beragam faktor. Masyarakat Badegan sebenarnya juga ingin melakukan diversifikasi mata pencaharian, akan tetapi keinginan tersebut terbentur oleh kemampuan pengetahuan dan skill.

Sulit beralihnya mata pencaharian membuat masyarakat Badegan termasuk masyarakat desa dengan kategori miskin. Data BPS mencatat sebanyak 20,82\% masyarakat Badegan adalah masyarakat miskin, 20,75\% sangat miskin. Dari data tersebut hampir setengah masyarakat Badegan adalah penduduk miskin dengan homogenitas mata pencaharian.

Homogennya mata pencaharian masyarakat Badegan, rendahnya tingkat pendidikan (baca=pengetahuan), dan tingkat keterampilan yang minim merupakan unsur-unsur penyusun kemiskinan. Untuk memotong mata rantai tersebut diperlukan ide kreatif yang mampu bernegosiasi dengan banyaknya kekurangan masyarakat Badegan. Ide yang mampu menyelaraskan antara kemampuan bertani yang sudah digeluti masyarakat Badegan sejak lama.

Melihat topografi Badegan yang dataran tinggi, maka solusi untuk memecahkan permasalahan akut ini adalah dengan melakukan diversifikasi tanaman pertanian. Petani tidak hanya menanam padi, tetapi juga tanaman pertanian lain yang memiliki nilai jual. Petani tidak hanya mengolah tanah pertanian tanpa tau apa yang harus dilakukan setelah panen, tetapi juga mampu mengolah hasil pertanian agar memiliki nilai jual yang lebih tinggi. Menjawab 
tantangan tersebut kiranya pertanian jamur tiram dirasa mampu menjadi alternatif untuk memotong mata rantai kemiskinan ini.

Jamur tiram dipilih sebagai alternatif mata pencaharian karena usia tanamnya yang pendek yaitu 3 bulan. Dengan usia pendek maka pertanian jamur tiram mampu dibudidayakan dengan cepat yang nantinya dapat membudaya di dalam masyarkat. Adanya banyak kelebihan pada tanaman jamur tiram menjadikan tanaman ini layak digunakan sebagai alternatif mata pencaharian masyarakat Badegan.

Implementasi dari program ini adalah pelatihan budidaya jamur tiram kepada masyarakat dusun. Mitir, kecamatan Badegan kabupaten Ponorogo. Penelitian dilakukan melalui partisipasi langsung ke dalam masyarakat. Sasaran adalah seluruh anggota masyarakat, karena menurut data BPS mayoritas masyarakat dsn. Mitir dikategorikan miskin.

Masyarakat menjadi obyek yang dilatih dan didampingi secara sementara oleh tim dari IAIN Ponorogo dan BLKI kabupaten Ponorogo yang berperan sebagai subyeknya. Tim pendamping berusaha memahamkan masyarakat akan pentingnya diversifikasi mata pencaharian, sehingga selama proses pendampingan masyarakat diarahkan untuk sadar akan peluang wirausaha di sektor ini. Jika masyarakat sudah sadar maka kerja tim pendampingan untuk memberi pengetahuan dan meningkatkan skill akan lebih mudah. Untuk menindaklanjuti rencana ini maka implementasinya sebagai berikut:

Pertama, pemetaan keluarga yang secara sadar bersedia untuk memulai budidaya jamur tiram atau yang bersedia untuk membentuk kelompok usaha jamur tiram. Kegiatan ini dilakukan sebelum dan sesudah pelatihan. Dilakukan sebelum pelatihan dengan tujuan mencari agen yang bersedia menerima pelatihan. Dilakukan sesudah kegiatan dengan tujuan mencari agen yang bersedia memulai usaha budidaya. Tentunya tahap pemetaan ini dapat dilakukan oleh masyarakat itu sendiri atau kantor desa setempat.

Kedua, pelatihan pertama yaitu pelatihan budidaya jamur tiram yang dilakukan oleh BLKI kabupaten Ponorogo. Pada pelatihan ini akan dijelaskan seluk beluk usaha budidaya jamur tiram mulai dari olah tanaman sampai olah hasil dan bermuara pada oleh-oleh jamur. Tim dari IAIN mempersiapkan keperluan pelatihan dan mendukung kelancaran acara tersebut.

Ketiga, pelatihan kedua yaitu pengelompokan masyarakat berdasarkan klaster: individu dan kelompok usaha. Pada tahapan ini tim pendamping mendampingi pembuatan rencana usaha termasuk penyusunan anggaran. Di samping itu pelatihan ini mempertemukan masyarakat dengan stakeholders (pemilik usaha warung, toko oleh-oleh, pemilik stan sayur di pasar, dll). Tujuan 
pertemuan dengan stakeholders untuk memperkuat jaringan kerja. Beberapa perwakilan pihak terkait juga turut diundang dalam pelatihan tahap kedua ini seperti: BLKI kabupaten Ponorogo, perwakilan IAIN Ponorogo, INDAGKOP, dan Disnaker.

\section{WIRAUSAHA DALAM KAJIAN}

Media pembelajaran sering juga disebut dengan istilah media pendidikan. Kedua istilah ini bisa dipergunakan secara bergantian dan mengandung makna yang relatifsama.Media pembelajaran merupakan suatu alat atau perantara yang berguna untuk memudahkan proses belajar mengajar, dalam rangka mengefektifkan komunikasi antara guru dan murid. Hal ini sangat membantu guru dalam mengajar dan memudahkan murid menerima dan memahami pelajaran.Perlu ditekankan bahwa proses ini membutuhkan peran guru yang profesional agar mampu menyelaraskan antara media pembelajaran dan metode pendidikan.

Penggunaan istilah wirausaha dalam pemakaiannya seringkali tumpang tinding dengan wiraswasta. Dalam berbagai referensi dapat dilihat bahwa penegertian wirausaha sama dengan wiraswasta. Dengan demikian penggunaan istitah wirausaha dapat mewakili wiraswasta. Istilah wirausaha berasal dari kata enterpreneur (bahasa Perancis). Jika diterjemahkan dalam bahasa Inggris sama dengan between taker atau go-between.

Perkembangan teori dan istilah enterpreneur secara beurutan sebagai berikut; Abad pertengahan: Berarti aktor atau orang yang bertanggung jawab dalam proyek produksi berskala besar. Abad 17 diartikan sebagai orang yang menanggung resiko untung rugi dalam mengadakan kontrak pekerjaan dengan pemerintah dengan menggunakan fixed price. Tahun 1725 Richard Cantillon menyatakan enterpreneur sebagai orang yang menanggung resiko yang berbeda dengan orang memberi modal. Tahun 1797, Bedeau menyatakan wirausaha sebagai orang yang menanggung resiko, yang merencanakan, supervisi, mengorganisasi, dan memiliki. Tahun 1803, Jean Baptist Say menyatakan adanya pemisahan antara keuntungan untuk wirausaha dan keuntungan untuk pemilik modal. Tahun 1876, Francis Walker membedakan antara orang yang menyediakan modal dan menerima bunga, dengan orang yang menerima keuntungan karena keberhasilannya memimpin usaha. Tahun 1934, Joseph Schumpter, seorang wirausaha adalah seorang inovator dan mengembangkan teknoilogi. Tahun 1961, David McLelland, enterpreneur adalah seorang yang mampu menanggung resiko. Tahun 1964, Peter Drucker, enterpreneur adalah seorang yang mampu memanfaatkan peluang. Tahun 1975, Albert Shapero, 
seorang yang memilikin inisiatif, mengorganisir mekanis sosial dan ekonomi, dan menerima resiko kegagalan. Ahun 1980, Karl Vesper seorang wirausaha berbeda dengan ahli ekonomi, Psikologis, Business Person, dan politikus. Tahun 1883, Gifford Pinchot, wirausaha adalah seorang enterpreneur dari dalam organisasi yang sudah ada/ organisasi yang sedang berjalan. Terakhir, Tahun 1985, Robert Hisrich: Enterpreneur is the process of creating something different with value bay devoting the necessary time and effort, assuming the accompanying financial, psycological, and social risk and receiving the resulting rewards of monetary and personal satisfaction. (Robert D. Hisrich dan Michael P. Peters, 1995:6).

Selain teori perkembangan wirausaha menurut ahli dari luar negeri, terdapat beberapa definisi wirausaha menurut para ahli dari dalam negeri. Achmad Sanusi mengartikan wirausaha sebagai suatu perwujudan nilai dalam perilaku yang menjadi pondasi, sumber daya, tujuan, kiat, proses, strategi, tenaga, penggerak, dan hasil usaha. Siswanto Sudomo, kewirausahaan adalah segala sesuatu yang penting mengenai seorang wirausaha, yakni orang yang memiliki sifat bekerja keras dan berkorban, memusatkan segala daya dan berani mengambl resiko untuk mewujudkan gagasannya. Eddy Soeryanto Soegoto mengartikan kewirausahaan sebagai usaha kreatif yang dibangun berdasarkan inovasi untuk menghasilkan sesuatu yang baru, memiliki nilai tambah, memberi manfaat, menciptakan lapangan kerja, dan hasilnya berguna bagi orang lain. Joko Untoro mendefinisikan konsep wirausaha sebagai suatu keberanian untuk melakukan upaya-upaya memenuhi kebutuhan hidup yang dilakukan oleh seseorang atas dasar kemampuan dengan cara memanfaatkan segala potensi yang dimiliki untuk menghasilkan sesuatu yang bermanfaat bagi dirinya sendiri dan orang lain. Syamsudin Suryana, Wirausaha ialah sosok yang penuh dengan rasa percaya diri, berani mengambil resiko, lugas dalam memimpin, penuh dengan kreativitas dan inovasi, serta mengorientasikan diri pada tanggung jawab, hasil, dan masa depan. Soeharto Prawiro mengatakan bahwa wirausaha sebagai sebuah nilai yang dibutuhkan untuk memulai usaha dan mengembangkan usaha. Terakhir menurut Prawirokusumo mengartikan wirausaha adalah orang yang selalu mengupayakan berbagai hal kreatif dan inovatif dengan cara pengembangan ide dan memanfaatkan setiap sumber daya yang ada, guna mendapatkan peluang untuk memperbaiki hidup.

Secara etimologi kewirausahaan berasal dari gabungan dua kata yakni wira dan usaha. Wira diartikan sebagai sifat jantan, laki-laki, pahlawan, perwira, pejuang, manusia unggul, teladan, berbudi luhur, berwatak agung, gagah, dan berani. Sedangkan usaha megandung arti ikhtiar, perbuatan, prakarsa, dan daya upaya. Kewirausahaan dapat diartikan sebagai hal-hal yang bersangkutan dengan 
keberanian seseorang untuk melaksanakan sesuatu kegiatan bisnis/non bisnis dengan peluang untung rugi.

Ada juga yang menyatakan bahwa wirausaha adalah keberanian atau juga kecakapan seseorang untuk menilai serta juga melihat suatu peluang dalam bisnis dan kemudian menyatukan suatu sumber daya yang diperlukan untuk pengambilan keputusan yang tepat dan tentunya mendapatkan keuntungan dalam rangka mencapai suatu keberhasilan.

Jadi dapat dikatakan bahwa pengertian wirausaha ditekankan pada seseorang yang mampu melihat adanya peluang kemudian menciptakan sebuah organisasi untuk memanfaatkan peluang tersebut. Definisi ini menekankan pada setiap orang yang memulai sesuatu bisnis yang baru. Sedangkan proses kewirausahaan meliputi semua kegiatan fungsi dan tindakan untuk mengejar dan memanfaatkan peluang dengan menciptakan suatu organisasi.

Seorang inovator dan wirausaha yang terkenal dan sukses membangun sebuah bisnis/usaha, umumnya mereka bukan penanggung resiko, tetapi mereka mencoba mendefinisikan resiko yang harus mereka hadapi dan mereka meminimalkan resiko tersebut. Jika kita berhasil mendefinisikan resiko kemudian membatasinya, dan mereka secara sistematis dapat menganalisis berbagai peluang, serta mengeksploitasinya maka mereka akan dapat meraih keuntungan membangun sebuah bisnis besar.

Dari beberapa pengertian wirausaha menurut para ahli di atas, kiranya dapat diambil perbedaan inti dari pengertian wirausaha. Ada yang mengartikan wirausaha sebagai orang yang menanggung resiko. Ada juga yang mengartikan sebagai orang yang mengurus perusahaan. Sementara yang lain mengartikan sebagai orang yang memobilisasi dan mengalokasikan modal. Pun demikian, dan ada yang mengartikannya sebagai orang yang mencipta barang baru.

Meskipun banyak terjadi perbedaan atas pengertian dari wirausaha. Pendapapat Schumpter tahun 1912 masih bayak diikuti oleh masyarakat. Pendapat Schumpter yang masih banyak diikuti dan diterima itu disebutkan oleh seorang penulis sebagai berikut:

"Bagi Schumpter seorang wirausaha tidak selalu seorang pedagang atau seorang manajer. Ia adalah orang yang unik yang berpembawaan pengambil resiko dan yang memperkenalkan produk-produk inovatif dan teknologi baru ke dalam perekonomian. Schumpter membedakan dengan tegas antara proses invention dengan inovation. Hanya sedikit pengusaha yang dapat melihat ke depan dan inovatif yang dapat merasakan potensi penemuan baru dan memanfaatkannya. Setelah pengenalan inivasi yang berhasil dari seorang 
wirausaha, maka wirausaha lainnya akan mengikuti dan produk atau teknologi baru itu tersebar dalam kehidupan ekonomi.

Kewirausahaan tidak dapat dipisahkan dari penganguran. Semakin maju sebuah negara, semakin terdidik dan berkualitas Sumber Daya Manusianya, tetapi semakin banyak tingkat pengangguran, maka kewirausahaan merupakan hal penting pemecah mata rantai pengangguran tersebut. Semakin suburnya wirausaha-wirausaha di Indonesia maka berelasi juga dengan tingginya tingkat APBN suatu negara. Pentingnya kewirausahaan dapat dilihat dari rincian manfaatnya sebagai berikut: 1) Menambah daya tampung tenaga kerja, sehingga dapat mengurangi pengangguran. 2) Sebagai generator pembangun lingkungan, bidang produksi, distribusi, pemeliharaan lingkungan, kesejahteraan, dan sebagainya. 3) Menjadi contoh bagi anggota masyarakat lain, sebagai pribadi unggul yang patut dicontoh, diteladani, karena seorang wirausaha itu adalah orang terpuji, jujur, pemberani, dan hidup tidak merugikan orang lain. 4) Selalu menghormati hukum dan peraturan yang berlaku, berusaha selalu menjaga dan membangun lingkungan. 5) Berusaha memberi bantuan kepada orang lain dan pembangunan sosial, sesuai dengan kemampuannya. 6) Berusaha mendidik karyawannya menjadi orang mandiri, disiplin, jujur, tekun dalam menghadapi pekerjaan. 7) Memberi contoh bagaimana kita harus bekerja keras, tetapi tidak melupakan perintah-perintah agama. 8) Hidup secara efisien, tidak berfoya-foya, dan tidak boros. DAN 9) Memelihara keserasian lingkungan, baik dalam pergaulan maupun kebersihan lingkungan.

Kewirausahaan yang notabene bermanfaat untuk mengatasi pengangguran ternyata juga tidak sepenuhnya menarik minat masyarakat. Banyak faktor psikologis yang membentuk sikap negatif masyarakat sehingga mereka kurang berminat terhadap profesi wirausaha, antara lain sikap agresif, ekspansif, bersaing, egois, tidak jujur, kikir, sumber penghasilan tidak stabil, kurang terhormat, pekerjaan rendah, dan sebagainya. Pandangan seperti dianut oleh sebagian besar penduduk, sehingga mereka tidak tertarik. Mereka tidak menginginkan anak-anaknya menerjuni bidang ini, dan berusaha mengalihkan perhatian anak untuk menjadi Pegawai Negeri Sipil, apalagi bila anaknya sudah bertitel lulus perguruan tinggi. Landasan filosof inilah yang menyebabkan rakyat Indonesia tidak termotivasi terjun ke dunia bisnis.

Wirausahawan adalah seorang inovator yang mempunyai semangat, kemampuan, dan pikiran untuk menakklukkan cara berpikir lamban dan malas. Seorang wirausaha mempunyai peran untuk mencari kombinasi-kombinasi baru yang merupakan gabungan dari lima hal: pengenalan barang dan jasa baru, 
metode produksi baru, sumber bahan mentah baru, pasar-pasar baru, dan organisasi industri baru.

Keuntungan dari melakukan kegiatan wirausaha antara lain; Terbuka peluang untuk mencapai tujuan yang dikehendaki sendiri. Terbuka peluang untuk mendemonstrasikan kemampuan serta potensi seseorang secara penuh. Terbuka peluang untuk memperoleh manfaat dan keuntungan secara maksimal. Terbuka peluang untuk membantu masyarakat dengan usaha-usaha konkrit. Dan Terbuka kesempatan untuk menjadi bos. Di samping keuntungan ternyata wirausaha memiliki beberapa kelemahan; Memperoleh pendapatan yang tidak pasti, dan memikul berbagai resiko. Jika resiko ini telah diantisipasi secara baik, maka berarti wirausaha telah menggeser resiko tersebut. Bekerja keras dan waktu/ jam kerjanya panjang. Kualitas kehidupannya masih rendah sampai usahanya berhasil, sebab dia harus berhemat. Dan Tanggung jawabnya sangat besar, banyak keputusan yang harus dia buat walaupun dia kurang menguasai permasalahan yang dihadapinya.

Untuk memulai sebuah proses wirausaha bagi pemula maka proses pertama yang harus dilakukan pertama kali adalah inovasi. Beberapa faktor pendorong inovasi adalah: keinginan berprestasi, adanya sifat penasaran, keinginan menanggung resiko, dan faktor pendidikan dan pengalaman. Disamping karena faktor inovasi yang tumbuh dari dalam, ada juga faktor yang tumbuh dari luar yaitu lingkungan sosial. Faktor lingkungan sosial ini meliputi: peluang, pengalaman, dan kreativitas.

Proses kedua adalah pemicu. Pemicu diartikan sebagai faktor yang memaksa seseorang untuk terjun ke dunia bisnis. Faktor pemicu dari seseorang memulai untuk melakukan usaha cukup banyak; Adanaya ketidakpuasan terhadap pekerjaan yang sekarang. Adanya PHK dan tidak ada pekerjaan lain. Dorongan karena faktor usia. Keberanian menanggung resiko. Dan komitmen atau minat yang tinggi terhadap bisnis. Adapun dari sisi Faktor-faktor lingkungan yang mendorong menjadi pemicu kegiatan wirausaha diantaranya; Adanya persaingan dalam dunia kehidupan. Adanya sumber-sumber yang bisa dimanfaatkan, misalnya memiliki tabungan, modal, warisan, memiliki bangunan yang lokasi strategis, dan sebagainya. Mengikuti latihan-latihan atau incubator bisnis. Sekarang banyak kursus-kursus bisnis dan lembaga manajemen fakultas ekonomi melaksanakan pelatihan dan incubator bisnis. Dan Kebijaksanaan pemerintah misalnya adanya kemudahan-kemudahan dalam lokasi berusaha ataupun fasilitas kredit, dan bimbingan usaha yang dilakukan oleh Depnaker.

Faktor sosiologis yang menjadi pemicu serta pelaksanaan bisnis adalah:

1. Adanya hubungan-hubungan atau relasi-relasi dengan orang lain. 
2. Adanya tim yang dapat diajak kerjasama dalam berusaha.

3. Adanya dorongan dari orang tua untuk membuka usaha.

4. Adanya bantuan keluarga dalam berbagai kemudahan.

5. Adanya pengalaman-pengalaman dalam dunia bisnis sebelumnya.

Langkah ketiga jika seseorang akan memulai kegiatan wirausaha adalah proses pelaksanaan. Proses pelaksanaan adalah tahapan aksi dari proses inovasi dan pemicu. Beberapa faktor personal yang mendorong pelaksanaan dari sebuah kegiatan wirausaha, yaitu:

1. Adanya seorang wirausaha yang sudah siap mental secara total.

2. Adanya menejer pelaksana sebagai tangan kanan, pembantu utama.

3. Adanya komitmen yang tinggi terhadap bisnis.

4. Adanya visi, pandangan yang jauh ke depan guna mencapai keberhasilan.

Proses terakhir yaitu tahap pertumbuhan. Tahapan pertumbuhan ini dipengaruhi oleh dua variabel besar yaitu organisasi dan lingkungan. Variabel organisasi adalah faktor utama yang menentukan keberhasilan suatu usaha dari segi struktural pengelolaannya. Berikut adalah faktor pendorong organisasi.

1. Adanya tim yang kompak dalam menjalankan usaha sehingga semua rencana dan pelaksanaan operasional berjalan produktif.

2. Adanya strategi yang mantab sebagai produk dari tim yang kompak.

3. Adanya struktur dan budaya organisasi yang sudah membudaya. Budaya perusahaan jika sudah terbentuk dan diikuti dengan penuh tanggung jawab oleh seluruh karyawan maka pertumbuhan perusahaan akan berkembang pesat.

4. Adanya produk yang dibanggakan, atau keistimewaan yang dimiliki misalnya kualitas makanan, lokasi usaha, manajemen, personalia, dan sebagainya.

Faktor lingkungan yang mendorong pertumbuhan bisnis, sebagai berikut:

1. Adanya unsur persaingan yang cukup menguntungkan.

2. Adanya konsumen dan pemasok barang yang kontinyu.

3. Adanya bantuan dari pihak investor bank yang memberikan fasilitas keuangan.

4. Adanya sumber-sumber yang tersedia, yang masih bisa dimanfaatkan.

5. Adanya kebijaksanaan pemerintah yang menunjang beberapa peraturan bidang ekonomi yang menguntungkan.

Jadi secara keseluruhan dapat disimpulkan bahwa ciri-ciri manusia yang memiliki jiwa wiraswasta adalah sebagai berikut:

1. Tahu apa maunya, dengan merumuskannya, merencanakan upayanya, dan menentukan program batas waktu untuk mencapainya. 
2. Berpikir teliti dan berpandangan kreatif dengan imajinasi yang membangun.

3. Siap mental untuk menyerap dan menciptakan kesempatan serta siap mental dan kompetensi untuk memenuhi persyaratan kemahiran mengerjakan sesuatu yang positif.

4. Membiasakan diri bersikap mental positif maju dan selalu bergairah dalam setiap pekerjaan

5. Mempunyai daya penggerak diri yang selalu menimbulkan inisiatif.

6. Tahu mensyukuri dirinya, waktu, dan mensyukuri lingkungannya.

7. Bersedia membayar harga kemajuan, yaitu kesediaan berjerih payah.

8. Memajukan lingkungan dengan menolong orang lain, agar orang lain dapat menolong dirinya sendiri.

9. Membiasakan membangun disiplin diri, bersedia menabung, dan membuat anggaran waktu luang.

10. Selalu menarik pelajaran dari kekeliruan, kesalahan, dan pengalaman pahit, serta berprihatin selalu.

11. Menguasai kemampuan jual, memiliki kepemimpinan, dan kemampuan memperhitungkan resiko.

12. Mereka berwatak maju dan cerdik, serta percaya pada diri sendiri.

13. Mampu memusatkan perhatiannya terhadap setiap pedagang

14. Berkepribadian yang menarik, memahami seni berbicara, dan seni bergaul.

15. Jujur, bertanggung jawab, ulet, tekun, dan terarah.

16. Memperhatikan kesehatan diri, tidak suka begadang, jangan menjadi perokok berat, tidak minum alkohol, dan narkoba.

17. Menjauhkan diri dari sifat iri, dengki, rakus, dendam, takut disaingi, khawatir dan ragu-ragu.

18. Tunduk dan bersyukur kepada Tuhan YME untuk mendapatkan ridhoNya, beriman, dan memperhatikan hukum tuhan, peraturan dan hukum yang berlaku sebagai pedoman.

Bagian terakhir adalah kategori-kategori dari wirausaha. Setidaknya ada empat kategori wirausahawan antara lain:

1. Penemu: Mendefinisikan konsep, unik, baru, penemuan, atau metodologi.

2. Inovator: Merupakan sebuah teknologi baru atau metodologi untuk memecahkan masalah baru.

3. Marketer: Mengidentifikasi kebutuhan di pasar dan memenuhinya dengan produk baru atau produk substitusi yang lebih efisien.

4. Oportunis: Pada dasarnya sebuah broker, pialang, yang menyesuaikan antara kebutuhan dengan jasa diberikan komisi. 
Mitos-mitos tentang wirausahawan yang menyatakan wirausahawan adalah pelaku bukan pemikir. Seringkali mereka adalah orang yang sangat metodis sehingga merencanakan tindakan mereka dengan hati-hati. Mereka dilahirkan tidak diciptakan. EAS discipline membantu untuk menghilangkan mitos ini. Seperti semua disiplin ilmu, wirausahawan memiliki model, proses, dan kasus yang memungkinkan topik untuk dipelajari.

Mereka adalah penemu misalnya Ray Krock. bukan dia yang menemukan waralaba makanan, tetapi ide-ide inovatifnya membuat McDonalds terkenal ke seluruh dunia. Mereka adalah orang akademik dan sosial. Keyakinan bahwa pengusaha adalah akademisi dan sosialis yang tidak berhasil akibat dari beberapa pemilik usaha yang memulai perusahaan yang sukses setelah putus sekolah atau berhenti bekerja tetapi tidak lagi dipandang demikian. Saat ini mereka dipandang sebagai seorang profesional. Orientasi wirausahawan adalah uang. Uang adalah sumber daya tetapi tidak pernah menjadi tujuan akhir. Semua membutuhkan keberuntungan, benar bila keberuntungan berada di tempat yang tepat pada waktu yang tepat akan selalu menghasilkan keuntungan. Tetapi keberuntungan terjadi ketika persiapan bertemu kesempatan.

Dalam suatu kegiatan wirausaha tidak sepenuhnya tepat sasaran. Ada beberapa kesalahan yang akhirnya membuat suatu wirausahawan mengalami kegagalan. Berikut adalah kesalahan-kesalahan dalam berwirausaha:

1. Kesalahan dalam mengelola.

2. Kurangnya pengalaman manajer bisnis kecil perlu memiliki pengalaman jika mereka ingin mengembangkan usahanya.

3. Kontrol keuangan kurang karena bisnis yang sukses membutuhkan kontrol keuangan yang tepat.

4. Upaya pemasaran yang lemah. Membangun konsumen untuk bertambah secara berkesinambungan membutuhkan usaha, pemasaran secara terus menerus dan kreatif.

5. Kegagalan untuk membangun rencana strategis. Gagal dalam merencanakan berarti gagal dalam bertahan.

6. Pertumbuhan tidak terkendali. Pertumbuhan adalah hal yang alami, sehat, dan didinginkan oleh setiap perusahaan. Namun, harus direncanakan dan dikendalikan. Pakar manajemen Peter Drucker berkata perusahaanperusahaan baru lebih baik untuk memperkirakan pertumbuhan modal hanya setiap peningkatan penjualan $40 \%$ hingga $50 \%$.

7. Lokasi kurang strategis. Memilih lokasi yang tepat adalah sebagian seni dan sebagian ilmu. Seringkali, lokasi bisnis dipilih tanpa penelitian yang benar, investigasi, dan perencanaan. 
8. Kontrol persediaan barang yang buruk. Pengendalian persediaan barang adalah salah satu tanggung jawab yang sering terabaikan.

9. Harga tidak tepat. Menetapkan harga yang tepat sehingga menghasilkan keuntungan yang diperkirakan menuntut pemilik bisnis mengerti berapa biaya untuk membuat, memasarkan, dan mendistribusikan barang-jasa.

10. Kurang mempunyai kemampuan dalam membuat transmisi enterpreneurial. Setelah memulai akan terjadi pertumbuhan, biasanya membutuhkan gaya manajemen yang sangat berbeda. Pertumbuhan mengharuskan wirausahawan untuk mendelegasikan wewenangnya dan tidak menanganikegiatan operasional sehari-hari sesuatu yang tidak biasa dilakukan olehnya. Jika membicarakan tentang kelemahan-kelemahan di atas, maka ada beberapa solusi pemecahannya, yaitu:

1. Mengenal bisnis secara mendalam.

2. Mengembangkan rencana bisnis yang matang.

3. Mengelola keuangan.

4. Memahami laporan keuangan.

5. Belajar mengelola manusia secara efektif.

\section{PELAKSANAAN DAN METODE}

Menurut data dari BPS Keadaan ekonomi masyarakat Mitir sebagian besar bermata pencaharian sebagai petani, selain sebagai petani masyarakat lain juga bermata pencaharian sebagai buruh pasir karena lokasi dusun yang berdekatan dengan sungai. Dari segi sosialnya masyarakat Dusun Mitir merupakan masyarakat yang multikultural, dan memiliki background yang berbeda.Permasalahan yang masih membayangi peta sosial dan ekonomi di Dusun Mitir adalah kurang adanya dukungan pengembangan pertanian yang masih rawan terjadinya konflik, karena latar yang berbeda. Selaian dua mata pencaharian sebagai petani dan penambang pasir mata pencaharian masyarakat dusun mitir adalah sebagai guru ataupun pegawai dan sebagai TKI yang mengadu nasib di luar negeri, hal ini disebabkan oleh sebagian besar masyarakat dusun Mitir adalah pekerja musiman, disaat tidak ada kesibukan banyak dari masyarakat yang menganggur.

Pola pikir semacam itu ditambah lagi dengan geografi daerah Mitir dengan topografi dataran rendah dan curah hujan yang banyak maka perlu dicari jenis usaha apa yang cocok untuk lingkungan alam dan lingkungan sosial. Melihat gejala sosial yang ada di Mitir bahwa umumnya perempuan di sana hanya sebagai ibu rumah tangga tanpa penghasilan, maka seharusnya perlu dicarikan alternative wirausaha yang dapat juga dilakukan oleh kaum perempuan. 
Dari hasil observasi dipastikan jenis usaha yang cocok adalah budidaya jamur tiram dan olahannya. Usaha budidaya jamur tiram dipilih karena umumnya lahan pekarangan masyarakat Mitir masih luas sehingga dapat dimanfaatkan untuk rumah jamur. Pertimbangan lainnya adalah budidaya jamur tergolang ringan dan tidak menyita waktu aktivitas domestik sehingga dapat juga dikerjakan oleh kaum perempuan khususnya ibu rumah tangga sehingga diharapkan akan menambah penghasilan rumah tangga.

Untuk menindaklanjuti rencana budidaya jamur di Mitir, maka segera disusun rencana kegiatan sosialisasi budidaya jamur yang dilaksanakan pada:

1. Hari/Tanggal : Selasa/15 Agustus 2017

2. Tempat : Rumah bapak Sukar, dsn. Mitir, ds. Karangjoho, Badegan, Ponorogo

3. Waktu : 10.00 s.d. selesai

4. Peserta : 41 orang

5. Jadwal Kegiatan : pada table 1

Table 1

Jadwal sosialisasi budidaya jamur tiram

\begin{tabular}{llll}
\hline No. & Waktu & Kegiatan & Ket \\
\hline 1 & $10.00-10.30$ & Pembukaan & Panitia \\
\hline 2 & $10-30-12.00$ & $\begin{array}{l}\text { Sosialisasi Wawasan } \\
\text { Jejamuran }\end{array}$ & Narasumber \\
\hline 3 & $12.00-13.00$ & Ishoma & \\
\hline 4 & $13.00-14.30$ & Praktik Pembuatan Log & $\begin{array}{l}\text { Narasumber dan } \\
\text { Masyarakat }\end{array}$ \\
\hline 5 & $14.30-15.00$ & Praktik Pemilihan Benih dan & Narasumber dan \\
& & Pembenihan & Masyarakat \\
\hline 6 & $15.00-15.30$ & Break Shalat & \\
\hline 7 & $15.30-17.00$ & Praktik Olahan Jamur (sate & Narasumber dan \\
& & jamur dan bakso jamur) & Masyarakat \\
\hline 8 & $17.00-17.15$ & Penutupan & Panitia
\end{tabular}

Adapun kegiatan pelatihan wirausaha jamur melalui beberapa tahap. Pertama, Pembuatan Kumbung. Kumbung biasanya dibuat dari bambu atau kayu. Dinding kumbung bisa dibuat dari gedek atau papan. Atapnya dari genteng atau sirap. Jangan menggunakan atap asbes atau seng, karena atap tersebut akan mendatangkan panas. Sedangkan bagian lantainya sebaiknya tidak diplester. Agar 
air yang digunakan untuk menyiram jamur bisa meresap. Di dalam kumbung dilengkapi dengan rak berupa kisi-kisi yang dibuat bertingkat. Rak tersebut berfungsi untuk menyusun baglog. Rangka rak bisa dibuat dari bambu atau kayu. Rak diletakkan berjajar. Antara rak satu dengan yang lain dipisahkan oleh lorong untuk perawatan. Ukuran ketinggian ruang antar rak sebaiknya tidak kurang dari $40 \mathrm{~cm}$, rak bisa dibuat 2-3 tingkat. Lebar rak $40 \mathrm{~cm}$ dan panjang setiap ruas rak 1 meter. Setiap ruas rak sebesar ini bisa memuat 70-80 baglog. Keperluan rak disesuaikan dengan jumlah baglog yang akan dibudidayakan. Berikut adalah foto dari kumbung yang dibuat oleh warga masyarakat dusun Mitir.

Jika kumbung selesai dibuat maka langkah selanjutnya adalah kitamenyiapkan media tanam atau baglog. Media tanam yang biasa digunakan untuk jamur tiram terdiri dari beberapa bahan yang dikombinasikan menjadi satu. Bahan-bahan tersebut antara lain; Serbuk gergaji kayu sebanyak $80 \%$ (100kg). Bekatul sebanyak 10-15\% (20kg). Kapur CaCo3 sebanyak 3\% (10kg). Calsium (7kg). Gipsum (1kg). Dan air kurang lebih 40-60\%.

Kedua, Pembuatan Baglog. Pembuatan media tanam (baglog) jamur tiram, diawali dengan pemilihan bahan baku yang baik. Adapun bahan bakunya antara lain: a) Serbuk kayu. Semua jenis kayu bisa digunakan, tetapi jangan menggunakan kayu bergetah yang menyengat seperti kayu pinus. Penggunaan serbuk kayu dapat dilakukan melalui dua jenis yaitu serbuk kayu lunak dan keras. Perbedaan antara penggunakan serbuk kayu lunak dan keras terletak pada waktu panen dan umur ekonomis baglog. Serbuk kayu lunak seperti albasia, jabon, dll memiliki waktu masa panen yang lebih cepat daripada serbuk kayu keras, tetapi baglog yang berasal dari serbuk kayu lunak memiliki umur ekonomis cenderung pndek.Serbuk kayu keras seperti mahoni, jati, dll memiliki waktu masa panan yang lebih lama daripada serbuk kayu lunak, tetapi baglog yang berasal dari serbuk kayu keras memiliki umur ekonomis cenderung lama. b) Dedak. Dedak yang digunakan yang hendaknya baru dan masih bagus, yang masih banyak mengandung menir padi. Jangan menggunakan dedak yang sudah menggumpal dan banyak kutunya, karena sebagian kontaminasi atau penyakit berasal dari dedak. c) Kapur $\mathrm{CaCo3}$. Bisa menggunakan kapur pertanian atau juga kapur untuk bangunan. d) Air. Gunakan air yang jernih, utamakan air tanah (sumur atau jetpam). Jika memakai air PDAM atau air hujan endapkan dahulu selama 3 hari.

Sedangkan alat-alat yang harus disediakan yaitu: Sekop, Plastik PP (ukuran 17x30, 17x35, 18x35, 20x40), Drum pengukusan (drum bekas oli atau minyak tanah), Plastik dan terpal untuk menutup drum waktu pengukusan. Cara mencampur media untuk membuat baglog, sebagai berikut: 
1. Ayak serbuk gergaji dengan menggunakan ayakan pasir untuk memisahkan potongan serbuk yang masih besar,

2. Campur bekatul, kapur, gips lalu diaduk sampai benar-benar rata, setelah rata tambahkan air bersih, jangan lupa mengukur ph serbuk gergaji(ph yg baik adalah 5-7) setelah itu campuran media ditutup dengan plastik dan dibiarkan mengompos minimal 1 hari. Semakin lama pengomposan akan semakin bagus.

3. Setelah tercampur rata, kucurkan air bersih secukupnya. Ciri adonan yang pas, saat adonan dikepal air tidak mengucur, kalo kepalannya dibuka adonan tidak pecah.

4. Untuk mengetahui media sudah tercampur dengan baik, cara mengetesnya apabila digenggam tidak keluar air dan apabila dilepas tidak pecah. Ukuran diatas cukup untuk 100 baglog. Dibawah ini adalah foto masyarakat dusun Mitir membuat baglog.

5. Setelah semua bahan penyusun baglog tercampur rata, maka langkah selanjutnya adalah memasukkan adonan bahan ke dalam plastik ukuran 18x35. Usahakan memasukkannya padat. Gunakan botol berisi air untuk memadatkannya.Ikat plastik yang berisi adonan serbuk kayu dengan tali rafia, atau cukup dipelintirkan dan dilipat bagian plastik yang tersisa di atasnya. Berikut adalah foto masyarakat dusun Mitir saat memasukkan adonan ke dalam plastik.

6. Setelah adonan dimasukkan ke dalam plastik putih berukuran 18x35, maka tahap selanjutnya adalah pasturisasi. Pasturisasi atau biasa disebut dengan pengukusan baglog. Langkah dari pasturisasi adalah sebagai berikut:

a. Kukus baglog yang sudah dimasukkan plastik dan diikat lehernya.

b. Wadah pengukus paling sederhana yang dapat digunakan adalah drum.

c. Satu drum dapat memuat sekitar 60 baglog. Prinsip kerja pasturisasi adalah memanfaatkan panas uap air pada suhu $95-110^{\circ} \mathrm{C}$ dalam waktu 8-10 jam.

d. Ketika suhu pengukusan telah mencapai $100^{\circ} \mathrm{C}$, pertahankan selama 5 jam. Biasanya, waktu yang dibutuhkan untuk mencapai suhu $100^{\circ} \mathrm{C}$, pertahankan selama 5 jam.

e. Biasanya waktu yang dibutuhkan untuk mencapai $100^{\circ} \mathrm{C}$ adalah 3 jam, tergantung dari kestabilan api di tungku.

f. Selanjutnya, wadah pengukus di buka dan didiamkan selama 5 jam agar suhu media tanam dalam baglog kembali normal.

g. Berikut ini adalah foto proses pasturisasi yang dilakukan oleh masyarakat dusun Mitir. 
7. Proses selanjutnya adalah inokulasi. Baglog yang telah dipasturisasi sebaiknya dipindahkan ke tempat inokulasi dan didiamkan selama 24 jam untuk mengembalikannya ke suhu normal. Ruangan inokulasi harus dalam ke adaan steril dan memiliki sirkulasi udara yang baik. Hal ini penting untuk meminimalisir tercemarnya baglog dari spora pathogen atau bakteri. Berikut tahap-tahap pengisisan bibit ke baglog.

a. Ambil botol bibit F3, lalu semprotkan alcohol ke botol tersebut. Panaskan sebentar mulut botol diatas api spiritus hingga sebagian kapas terbakar, lalu matikan api yang membakar kapas.

b. Setelah kapas penyumbat botol bibit dibuka, aduk-aduk menggunakan kawat yang sudah disterilkan diatas api.

c. Masukkan binit dari botol ke baglog hingga leher baglog penuh, lalu tutup kembali dengan kapas. Setiap balog diisi sekitar $10 \mathrm{~g}$ bibit.

Setelah melalui tahap inokulasi, maka berikutnya adalah tahap inkubasi. Inkubasi atau pemeraman bertujuan agar bibit yang telah diinokulasi segera ditumbuhi miselium. Untuk menunjang pertumbuhan miselium. Untuk menunjang pertumbuhan miselium pada jamur tiram, idelanya ruang inkubasi memiliki suhu $24-29^{\circ} \mathrm{C}$, kelembapan 90-100\%, cahaya 500-1.000 lux, dan sirkulasi udara 1-2 jam. Setelah 15-30 hari masa inkubasi, biasanya miselium sudah tumbuh hingga separuh bagian baglog. Bila miselium telah memenuhi baglog, pertanda baglog siap dipindahkan ke rumah kumbung untuk dibudidayakan hingga proses pemanenan. Namun, bila dalam waktu 1 bulan dari masa inkubasi baglog tidak ditumbuhi misellium, berarti proses inokulasi yang dilakukan tidak berhasil.

\section{HASIL DAN PEMBAHASAN}

Masyarakat dusun mitir cukup antusias dan bersemangat untuk memulai usaha budidaya jamur tiram. Hal diskusi tim pendamping bersama masyarakat, diperoleh gambaran bahwa masyarakat mitir memang membutuhkan peluang usaha untuk meningkatkan pendapatan dan penghasilan keluarga.

Masyarakat tiram bersama dengan tim pendamping sejak awal mencoba mengidentifikasi kemungkinan jenis usaha yang diperkirakan cocok dengan kondisi alam dan lingkungan di desa mitir. Identifikasi berjalan cukup intensif disertai musyawarah yang cukup hangat. Proses ini membutuhkan waktu yang cukup lumayan. Hal tersebut dikarenakan bahwa disadari bersama untuk menentukan jenis usaha bersama membutuhkan kesepakatan dan kesepahaman 
bersama. Sebab dengan kesepakatan dan kesepahaman tersebut, akan memudahkan untuk menyusun langkah bersama kedepan.

Melalui diskusi yang cukup Panjang, diperoleh kesepakatan bersama bahwa masyarakat mitir akan mulai usaha budidaya jamur tiram. Pemilihan ini berangkat dari potensi sumber daya manusia, potensi lingkungan, dan potensi pasar yang mungkin dijangkau oleh masyarakat mitir. Dengan mengacu pada ketiga patokan ini, diharapkan akan menghasilkan usaha bersama yang berhasil dan sukses ke depan.

Langkah selanjtnya menyiapkan tim pengelola jamur tiram dan tim produk olahannya. Kedua tim ini dibentuk untuk memastikan bahwa jamur tiram dikelola dengan baik. Pun selanjutnya, dapat dipasarkan atau dibuat produk olahan dulu untuk selanjutnya dipasarkan. Oleh karena itu, tim pendamping menyiapakan program pelatihan budidaya jamur tiram dan pelatihan produk olahan jamur tiram.

Dalam proses yang berjalan selama pelatihan, tampak antusiasme masyarakat untuk mencoba memulai usaha baru mereka. Peserta pelatihan budidaya misalnya, mereka memanfaatkan segala potensi yang ada di lingkungannya untuk melengkapi kebutuhan bahan-bahan pembuatan tempat persemaian jamur tiram. Juga menyediakan lokasi yang cukup dan memadai untuk membudidayakan jamur tiram.

Pada sesi pelatihan produk olahan jamur tiram, tim pendamping dan masyarakat memilih produk olahan berupa jamur krispi dan sate jamur. Masyarakat mitir menyadari, meskipun nantinya jamur tiram bisa dipasarkan dalam bentuk jamur mentah, akan lebih menghasilkan bila dipasarkan dalam bentuk produk olahan. Hal tersebut juga untuk mengantisipasi jika jamur mentah tidak semuanya terserap untuk dipasarkan. Sehingg perlu dilakukan upaya menjadi produk olahan agar jamur tiram tersebut tidak rusak dan terbuang percuma.

\section{KESIMPULAN}

Dari hasil kegiatan pengabdian masyarakat tentang budidaya jamur yang diselenggarakan di dusun Mitir, Kec. Badegan, Kab. Ponorogo, dapat sebuah simpulan. Pada hakikatnya, masyarakat terbuka peluangnya untuk mencapai tujuan yang dikehendaki sendiri. Mereka terbuka peluangnya untuk mendemonstrasikan kemampuan serta potensi seseorang secara penuh, juga untuk memperoleh manfaat dan keuntungan secara maksimal. Di samping itu, 
masyarakat terbuka lebar peluangnya untuk membantu masyarakat dengan usaha-usaha konkrit, bahkan hingga untuk menjadi bos.

\section{DAFTAR PUSTAKA}

Alma. Buchari. Kewirausahaan. Bandung: Alfabeta. 2017.

BPS Kabupaten Ponorogo.Statistik Daerah Kecamatan Badegan 2016. Ponorogo:

BPS Kabupaten Ponorogo, 2016.

Kasali, Rhenalds. Wirausaha Muda Mandiri. Jakarta:Gramedia Pustaka Utama. 2011.

Poerwadarminta.WJS. Kamus Umum Bahasa Indonesia Jakarta: Balai Pustaka, 1999.

Soekanto Soerjono.SosiologiSuatu Pengantar. Jakarta: PT. Raja Grafindo Persada. 2015.

Soehadi. Agus, dkk. Enterpreneurship Education. Jakarta: Prasetya Mulya Publishing. 2011.

Suherman, Eman. Desain Pembelajaran Kewirausahaan. Bandung: Alfabeta. 2008. 